\title{
Occupational-related Stress among University Faculty Staff in Kwara State, Nigeria: Outcomes on Goal Achievement
}

\author{
Martins Olanrewaju Atunde ${ }^{I^{*}} \odot$, Johnson Abiodun Medupin ${ }^{\circledR}$, Saliu Ishaq Alabi ${ }^{3}{ }^{\odot}$, \\ Abdulganiyu Adebayo Tijani ${ }^{4}{ }^{\oplus}$, Olabode Awarun ${ }^{5}{ }^{\oplus}$, Janet Oluwakemi Oladejobi ${ }^{4}{ }^{\oplus}$, \\ Rasheedat Modupe Oladimeji $i^{2}{ }^{\oplus}$, Christiana Abosede Maiye ${ }^{6} \odot$
}

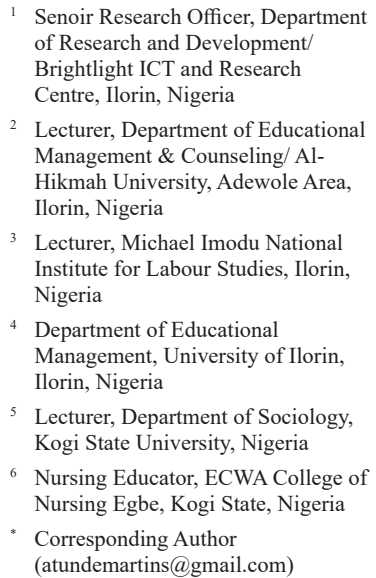

2 Lecturer, Department of Educational Management \& Counseling/ Al-

Hikmah University, Adewole Area, Ilorin, Nigeria

3 Lecturer, Michael Imodu National Institute for Labour Studies, Ilorin, Nigeria

4 Department of Educational Management, University of Ilorin, Ilorin, Nigeria

5 Lecturer, Department of Sociology, Kogi State University, Nigeria

6 Nursing Educator, ECWA College of Nursing Egbe, Kogi State, Nigeria

* Corresponding Author (atundemartins@gmail.com)

Received: 24 August, 2020

Revised: 10 October, 2020

Accepted: 08 November, 2020

Published: 15 December, 2020

How to cite this paper:

Atunde, M.O., Medupin, J.A. Alabi, S.I., Tijani, A.A., Awarun, O., Oladejobi, J.O., Olandemeji, R.M., \& Maiye, C.A. (2020). Occupationalrelated stress among university faculty staff in Kwara State, Nigeria: Outcomes on goal achievement. Quest Journal of Management and Social Sciences, 2(2), 307-322.

Copyright (C) 2020 by authors and Quest Journal of Management and Social Sciences.

This work is licensed under a Creative Commons Attribution-Non Commercial-No Derivatives 4.0 International License.

https://creativecommons.org/ licenses/by-nc-nd/4.0/

\section{Open Access}

\section{Abstract}

Background: Incidents of occupational stress among academicians globally is on the rise, despite its impending effects and prospects of coping strategies suggested in literature.

Objective: This study examines occupational stress among university faculty staff and its outcomes on university goal achievements in Kwara State, Nigeria.

Methods: The study was a cross-sectional survey. A multi-stage sampling technique was used for the selection of 458 faculty staff. Data were collected with the use of a 57 -item questionnaire.

Results: Results reveal that the level of stress among faculty staff was high (3.25), while stress level differs based on gender $(p<.05)$, age $(p<.01)$, marital status $(\mathrm{p}<.01)$, work experience $(\mathrm{p}<.05)$ and ownership of workplace $(\mathrm{p}<.05)$. The prominent risk associated with occupational-related stress are organizational-related (cluster mean 3.26) and role-related (CM 3.26) factors. Findings further indicate that the social support (CM 3.00) and individualfocused (CM 2.91) coping strategies were moderately adopted for managing occupational-related stress among university faculty, while the organizational support coping strategy was utilized to a low extent (CM 2.47).

Conclusion and Recommendation: The study findings implicate the attainment of university goals in terms of delivering quality teaching, research and promoting scholarship and community service. Thus, the mitigation of occupational-related stress requires individual, social and most especially workplace-level interventions.

Implications: The research would enable university administrators in designing appropriate workplace policies and intervention strategies or programmes for minimizing high-stress level, risk factors and their attendant effects so that faculty staff can cope effectively with work demands for the enhanced achievements of university goals.

Keywords: Coping Strategies; Goal Achievement; Risk Factors; Sociodemographic Parameters; Stress Level

Paper Type: Research Paper

JEL Classification: N37, I25, J11 


\section{Introduction}

Universities worldwide are the climax of any educational system, which is in turn adept in solving societal problems as well as fostering socio-economic, cultural, political, scientific and technological evolution of any country. In this regard, the Federal Government of Nigeria, through its National Policy on Education, spelt out the goals of university education to include the: provision of accessible and affordable quality learning opportunities; production of qualitative research; production of skilled manpower relevant to labour market needs; and promotion of scholarship, entrepreneurship and community service (Federal Republic of Nigeria [FRN], 2013). For the attainment of these goals, faculty staff otherwise known as academic staff, faculty members or lecturers, are indispensable and essential. This is because they are mandated to instruct (teach), conduct research, publish research findings and participate in community services; all of which aid the achievement of university goals. In order to effectively fulfill these mandates, researchers (Azizah, Rozainee, Nada, Izreen \& Norhafizah, 2016; Nguyen \& Nguyen, 2017; Usoro, 2018) observed that faculty employees within the university system are constantly pressurized, which resultantly makes them suffer from workplace stress. On this note, Sabherwal, Ahuja, George and Handa (2015) discussed occupational-related stress as the physical, physiological and psychological effect brought about by incompatibility between job requirements and the capabilities, resources and needs of faculty staff to cope with job demands.

A study by Amoako, Gyamfi, Emmanuel and David (2017), Gawati (2017) and Kumar and Rajeswari (2017) however, reported independently that stress encountered by faculty staff are related to workaholism, being too perfect, unconducive working environment, heavy workload inadequate staffing, long working hours, busy schedules, lack of motivation at work, lack of work equipment and tools, denial of job promotions and training opportunities and other institutional factors like long hours of work, hazardous conditions, job insecurity, non-participation in decision-making processes, non-availability of welfare facilities (Farenia, Wahyu, Purba \& Hatta, 2018) co-workers relationship problems and a never-ending workload. It could be inferred from the foregoing that the risk-factors or biomarkers of different occupational stress level are numerous and cannot be attributed to any universal risk factor. They can be inferred to a variety of factors, which can be related to personal or psychological, job roles, social, physical/environmental, and organizational factors. In this regard, Kumar and Rajeswari (2017) observed that, although stress originates from a mixture of factors in our personal, environmental and working lives, if it is not taking cognizance of early, it can increasingly lead to a decline in work performance, poor health status and increased work absentees in the longterm. In some extreme situations, long-term stress may lead to emotional and psychological problems, which are conducive to psychiatric disorders, restraining workers from being able to effectively discharge their statutory duties. This lends credence to why Gawati (2017) tagged occupational stress an "organizational challenge of the 21st Century". Hence, it is germane that every occurrence of stress be properly managed to ensure that such negativity, trauma, physiological, psychological, behavioural effects are minimized if not eliminated. This can be best achieved by adopting effective coping strategies.

Coping strategies are those measures, techniques, mechanisms, and behaviours which faculty staff utilises to adjust, manage and cope with their varied stress levels encountered or experienced in the cause of discharging their statutory duties. This transcribes that many techniques can be used by faculty staff to relieve themselves from stress. Betonio (2015) and Nkemakolam (2016) identified electronic technologies (like accessibility to video cassettes, digital videos, television, radio and online newspapers), involvement in exercises and relaxation therapies and social media activities are one of the best approaches to reduce work stressors. Also, ensuring a healthy family life, a good understanding of the nature of work, a good knowledge of how to control one's emotions, and good rest after long work, are the best ways to cope with stress (Nguyen \& Nguyen, 2017; Omoniyi, 2016). In their contributions, Farenia et al. (2018) suggested that redesigning job roles, organizing health 
talks, and assuming a positive attitude as good stress coping strategies. In view of these suggested coping strategies in literature, it can be inferred that faculty staff can design individual routine coping measures for themselves; receive social support from their families, co-workers and superiors; as well as be provided with support programmes by their organization.

Despite the influx and prospects of coping strategies suggested in literature, the incidents of occupational stress among the academicians globally is on the rise. The objective of this research is to investigate occupational-related stress among university faculty staff and its outcomes on university goal achievements in Kwara State, Nigeria.

In achieving the mentioned objective, the following research questions were raised to guide the study:

1. What is the level of occupational-related stress among university faculty staff in Kwara State?

2. Does the stress level of faculty staff differ based on their social demographic parameters of gender, age, marital status, work experience, and ownership of the workplace?

3. What are the risk factors associated with occupational stress among university faculty staff in Kwara State?

4. To what extent are coping strategies adopted for managing occupational-related stress among university faculty staff in Kwara State?

The study was however organized as follows: Section 2 explores the literature review, Section 3 covers research methodology, Section 4 shows the findings and results and, lastly, Section 5 discusses the findings and results as well as draws a conclusion and presents recommendation based on the research.

\section{Review of Literature}

\section{Theoretical Review}

Different theories and models theorizing stress, its processes, risk factors, effects and coping measures have been proposed by scholars and psychologists. This, amongst others, includes the Cognitive Appraisal Theory, Effort-Reward Imbalance theory, Job Demand-Control (JDC) theory, PersonEnvironment Fit theory, Schachter-Singer Theory, Theory of Emotional Emergency, Transactional Theory, Allostatic Load Model, and Conservation of Resources Model (Encyclopedia of Occupational Health and Safety [EOHS], 2011; Pezaro, 2018). However, as a result of the fact that the majority of the aforementioned theories and models cannot explicitly explain the tenets of this study, the present research adopted the Revised Transactional Model (RTM) suggested by Goh, Sawang and Oei in 2010, as its theoretical tenets. This model, which is a combination of both the transactional theory and JDC theory, explains the evolution of stress and how human beings experience, examine, handle and present the outcomes of occupational stress in the workplace (Pezaro, 2018). This evolution first engrosses an individual coming across or experiencing stres and observes their experience of it. Thereafter, the model explains how the individual then goes on to a second step of risk examination, where coping strategies are triggered in reply to the individual's exposure to the initial stressor. Summarily, the RTM model is germane to this study as it presents the encounter of stress, risk factors, coping styles as well as its evolvement of devastating causatum on both the individual and workplace at large; and that each level of stress can be explained by socio-demographic parameters.

\section{Empirical Review}

A plethora of research work/studies on occupational stress have emanated across the globe (Asia, America, Europe, and Africa) over the years. Notably, result from studies conducted in Indonesia (Gunawan, Deo, Hidayat, Pandia, Iskandar, Yuni et al., 2018), Vietnam (Nguyen \& Nguyen, 2017), Malaysia (Azizah et al. 2016; Ismail \& Noor, 2016; Noormaliza, Najibah, Fauzana, Azizah \& Nukhdiha, 2016), India (Sabherwal et al., 2015) and Nigeria (Peretomode, 2015) showed that faculty staff experienced between low to the moderate occupational stress level. Contrarily, research was also 
carried out in Malaysia (Zuraida \& Nur, 2015; Safaria, 2013), Japan (Kataoka, Ozawa, Tomotake, Tanioka \& King, 2014), and Zimbabwe (Masuku \& Muchemwa, 2015) showed that participants are encountering a high level of stress in discharging their duties. Risk factors of occupational-related stress are multi-dimensional and cannot be attributed to one single factor. Results on the impact of stress have also been conflicting with studies by Amoako et al. (2017), Kusi, Codjoe and Bampo (2018) and Usor (2018), reporting that faculty staff experience negative aftermaths of stress (health-related problems). However, Foy (2015), Sabherwal et al (2015) and Peretomode (2015) observed that stress does not have any negative effect on the performance of the faculty staff but propels them to work harder.

Despite the diverse research that have produced conflicting results that underscore the signification of undertaking this research; many of the previous studies have other shortcomings that created a research gap. Observatory literature trends on the influence of demographic parameters like age, gender, marital status, place of work, and professional experience on stress level among faculty staff, were also found to be incohesive. While some studies (Azizah el al., 2016; Adebiyi, 2013; Chaudhry, 2013; Foy, 2015; Gunawan et al., 2018; Noormaliza et al., 2016) reported that social demographic parameters had a positive effect and linkages with stress levels; others (Amoako et al., 2017; Ismail, Abd Rahman \& ZainalAbidin, 2014; Ismail \& Noor, 2016; Masuku \& Muchemwa, 2015; Nguyen \& Nguyen, 2017; Omoniyi, 2016) found no connections. Likewise, the implications of the stress level, as explained by socio-demographic parameters on the attainment of university goals within the study location, have not being given attention in the research paradigm. Additionally, a geographical gap exists as previous studies were not conducted within the geographical confines of Kwara State, Nigeria.

\section{Research Method}

The research methodology adopted in this study is the descriptive research of a cross-institutional survey. The study population comprised of 2,347 faculty staff in five universities (Kwara State University, Malete - 425; the University of Ilorin, Ilorin - 1,489; Al-Hikamah University, Ilorin - 157; Crown Hill University Eiyenkorin - 26; Landmark University, Omu-Aran - 219; Submit University, Offa - 31) in Kwara State, Nigeria (National Universities Commission, 2018). From the targeted population, 448 faculty staff were drawn through multi-stage sampling techniques. Stage 1 involves the stratification and selection of the study population based on types (Universities: public and private). Stage 2 involves the selection of two universities respectively from each of the stratified types through a purposive sampling technique. These universities were chosen based on the population of faculty staff and years of establishment. Specifically, two public (Kwara State University, Malete, Ilorin and the University of Ilorin, Ilorin) and private universities (Al-Hikamah University, Ilorin and Landmark University, Omu-Aran) were sampled for the study. Stage 3 involves the selection of participants through the convenience, stratified and proportionate sampling technique, by selecting $20 \%$ from each sampled universities. The percentage of faculty staff sampled for this study aligns with the position of Atunde (2011) that $20 \%$ of the target population is not too little for empirical research because they are manageable, accessible and will not create problems in terms of cost.

A validated, reliable (see Table 1) and structured research instrument titled: "Occupational-Related Stress Index Questionnaire" (ORSIQ) was utilized for data collection.

Table 1: Reliability Coefficients

\begin{tabular}{|c|c|c|c|}
\hline S.N. & Variables & Number of Items & Cronbach's Alpha Values \\
\hline 1 & Stress Level & 10 & .892 \\
\hline 2 & Risk-Factors & & \\
\hline a. & Personal-related & 5 & .813 \\
\hline
\end{tabular}




\begin{tabular}{|c|c|c|}
\hline Role-related & 5 & .884 \\
\hline Social & 5 & .781 \\
\hline Physical/environmental & 5 & .806 \\
\hline Organizational-related & 5 & .852 \\
\hline Reliability Index & 25 & .827 \\
\hline Coping Strategies & & \\
\hline Individual & 7 & .812 \\
\hline Social support coping strategy & 7 & .840 \\
\hline Organizational support coping strategy & 8 & .793 \\
\hline Reliability Index & 22 & .815 \\
\hline OVERALL RELIABILITY INDEX & 57 & .845 \\
\hline
\end{tabular}

The collection of data for the study which utilized the direct delivery technique was carried out between November 2019 and January 2020. In this regard, 440 out of 458 administered questionnaires were returned and filled correctly, implying a $96.1 \%$ response rate. Besides, appropriate and relevant descriptive and inferential statistics such as percentages, mean, standard deviation, t-test and analysis of variance (ANOVA) was used to analyse the data collected, based on the research questions raised to guide the study.

\section{Data Analysis and Results}

The results of the study were presented in Tables 2, 3, 4, 5, and 6 based on the socio-demographic parameters of participants. The research questions that guided the study were presented similarly.

Table 2 indicates the socio-demographic parameters of sampled university faculty staff in Kwara State, Nigeria. From the tables, a good portion $(56.1 \%)$ of faculty staff were male, while the remaining $43.9 \%$ were female. Concerning the age group of participants, $11.1 \%$ were between $21-30$ years of age, $28.0 \%$ were between 31 - 40 years, the majority (34.6\%) were between $41-50$ years, $17.7 \%$ were between $51-60$ years, while the remaining $8.6 \%$ of the faculty staff were above 60 years. On the distribution of faculty staff by their marital status, Table 2 further shows that the majority $(64.3 \%)$ of faculty staff were married, $19.1 \%$ were still single, while $14.3 \%$ were either widowed, divorced or separated. Statistics of the work experiences of faculty staff in the studied universities showed that $10.0 \%$ had between 1 and 5 years working experience, 26.6\% had between 6 and 10 years of work experience, $43.6 \%$ had between 11 and 15 years, while $19.8 \%$ had more than 16 years of working experience. The ownership of participant's workplace parameters showed that a large portion $(83.2 \%)$ worked in public universities, while the remaining $16.8 \%$ worked with private universities.

Table 2: Distribution of Respondents Based on their Socio-Demographic Parameters

\begin{tabular}{lcc}
\hline \multicolumn{1}{c}{ Parameters } & Frequency & Percentage (\%) \\
\hline Gender & 193 & 43.9 \\
Female & 247 & 56.1 \\
Male & $\mathbf{4 4 0}$ & $\mathbf{1 0 0}$ \\
Total & & \\
Age Group & 49 & 11.1 \\
21-30 yrs & 123 & 28.0 \\
$31-40$ yrs & & \\
\hline DOI 10.3126/qjmss.v2i2.33301 & 311 & QJMSS (2020)
\end{tabular}




\begin{tabular}{|c|c|c|}
\hline $41-50$ yrs & 152 & 34.6 \\
\hline $51-60 \mathrm{yrs}$ & 78 & 17.7 \\
\hline 60 yrs and above & 38 & 8.6 \\
\hline Total & 440 & 100 \\
\hline \multicolumn{3}{|l|}{ Marital Status } \\
\hline Single & 84 & 19.1 \\
\hline Married & 283 & 64.3 \\
\hline Widowed/Divorced/Separated & 63 & 14.3 \\
\hline Total & 440 & 100 \\
\hline \multicolumn{3}{|l|}{ Years of Experience } \\
\hline $1-5 \mathrm{yrs}$ & 44 & 10.0 \\
\hline $6-10 \mathrm{yrs}$ & 117 & 26.6 \\
\hline $11-15$ yrs & 192 & 43.6 \\
\hline 16 yrs and above & 87 & 19.8 \\
\hline Total & 440 & 100 \\
\hline \multicolumn{3}{|l|}{ Ownership of Workplace } \\
\hline Public & 366 & 83.2 \\
\hline Private & 74 & 16.8 \\
\hline Total & 440 & 100 \\
\hline
\end{tabular}

Key: $[1-5 y r s+6-10 y r s=$ less experience]; $[11-15 y r s+16 y r s$ and above $=$ experienced].

The statistical outcome from Table 3 shows that items $8,4,3,9,2$, and 6 respectively with mean values, $3.22,3.19,2.99,2.96,2.95$ and 2.78, indicate a moderate (mild) level of occupational-related stress among faculty staff. Also, items 1, 7, 10 and 5, with mean values 3.82, 3.75, 3.56 and 3.25 respectively, indicate a high level of occupational-related stress. Summarily, the grand mean value of 3.25 indicates that the level of occupational-related stress among university faculty staff is high.

Table 3: Occupational-Related Stress Level among University Faculty Staff

\begin{tabular}{|c|c|c|c|c|}
\hline S.N. & Items & $\bar{X}$ & Std. Deviation & Decision \\
\hline 1 & $\begin{array}{l}\text { I have to work very intensively every day to achieve } \\
\text { my daily job demands. }\end{array}$ & 3.82 & .50 & HL \\
\hline 2 & $\begin{array}{l}\text { Sometimes I have trouble concentrating during } \\
\text { work hours. }\end{array}$ & 2.95 & 0.90 & ML \\
\hline 3 & $\begin{array}{l}\text { I oftentimes forget things so easily during working } \\
\text { hours. }\end{array}$ & 2.99 & 0.91 & ML \\
\hline 4 & $\begin{array}{l}\text { Sometimes, I suddenly become moody/ and or feel } \\
\text { like to be alone during work hours. }\end{array}$ & 3.19 & .78 & ML \\
\hline 5 & $\begin{array}{l}\text { I sometimes feel tense, irritated and annoyed when } \\
\text { at work. }\end{array}$ & 3.25 & .68 & HL \\
\hline 6 & $\begin{array}{l}\text { I sometimes feel bored, depressed, and lose interest } \\
\text { in what I am doing during working hours. }\end{array}$ & 2.78 & .86 & ML \\
\hline 7 & By the time I finish the day job I feel fatigued/tired. & 3.75 & .59 & HL \\
\hline
\end{tabular}


8 On getting home from work, I oftentimes take $3.22 \quad .79 \quad$ ML analgesic drugs before sleeping.

$9 \quad 1$ sometimes have problems sleeping well at night $\quad 2.96 \quad .72 \quad$ ML after a day of work.

10 I sometimes feel apprehensive about going to work $\quad 3.56 \quad .60 \quad$ HL the next day (morning).

GRAND MEAN

3.25

.73

HL

Mean score between 3.25-4.00 = High Level (HL), 2.50-3.24 = Moderate Level $(M L)$, and $>2.50=$ Low Level (LL). This applies to both individual and grand mean values.

Table 4 revealed the statistical outcomes of the differences in the stress levels of faculty staff based on their social demographic parameters of gender, age, marital status, work experience and workplace ownership. The analysis of the test of equality revealed that the faculty staff from the two categories of gender (male and female) were significantly different from each other in respect to their stress level $(\mathrm{t}$-value $=3.268$, $\mathrm{p}$-value $=.001)$. ANOVA test results on age differences indicate that there is a statistically significant difference among stress levels of university faculty staff in Kwara State in terms of age $(\mathrm{F}=5.146, \mathrm{p}=0.000)$. The results in Table 4 also revealed that faculty staff who are single (M $2.9101, \mathrm{SD}=.71452$ ) had moderate level of occupational-related stress compared to those who are married $(\mathrm{M}=3.3400, \mathrm{SD}=.70200)$, and divorced/separated/widowed $(\mathrm{M}=3.5120, \mathrm{SD}=.63414)$ had high level of occupational-related stress (overall $F=3.660, p=.006$ ). Statistical analysis in Table 4 also revealed that the stress level of university faculty staff were significantly ( $t$-value $=3.891$, $p$-value $=.003$ ) different based on their work experiences (experience and less experience). Additionally, the output of the t-test analysis revealed that the stress level of faculty staff differs based on their ownership of the workplace ( $\mathrm{t}$-value $=4.570$, $\mathrm{p}$-value $=.000)$.

Table 4: Inferential Analysis of Stress Level and Social Demographic Parameters

\section{Inferential Statistics}

\begin{tabular}{|c|c|c|c|c|c|}
\hline \multicolumn{6}{|c|}{ t-test results of the difference in the stress level of faculty staff based on their gender } \\
\hline Gender & Mean & Std. Deviation & t-value & Sig. & Remarks \\
\hline Female & 3.3397 & .71304 & 3.268 & $.001 *$ & Significant difference exists \\
\hline Male & 3.1543 & .78520 & & & $(\mathrm{p}<.05)$ \\
\hline
\end{tabular}

One-way ANOVA results of the influence of age on stress level of faculty staff

\begin{tabular}{|c|c|c|c|c|c|}
\hline Age & Mean & Std. Deviation & $\mathbf{F}$ & Sig. & Remarks \\
\hline $21-30 \mathrm{yrs}$ & 2.8109 & .98100 & 5.146 & $.000 * *$ & Groups: 'different. " $21-30$ \\
\hline $31-40 \mathrm{yrs}$ & 3.0042 & .79120 & & & yrs' and '61 yrs and above' \\
\hline $41-50$ yrs & 3.2784 & .76512 & & & are statistically different. \\
\hline $51-60 \mathrm{yrs}$ & 3.4780 & .69015 & & & ' $31-40$ yrs' and ' $51-60 y r s$ ' \\
\hline $\begin{array}{l}61 \text { years and } \\
\text { above }\end{array}$ & 3.6803 & .34308 & & & $\begin{array}{l}\text { are statistically significantly } \\
\qquad(\mathrm{p}<.01)\end{array}$ \\
\hline
\end{tabular}


One-way ANOVA results of the influence of marital status on stress level

\begin{tabular}{|c|c|c|c|c|c|}
\hline Marital Status & Mean & Std Deviation & $\mathbf{F}$ & Sig. & Remarks \\
\hline Single & 2.9101 & .81452 & 3.660 & $.006^{* *}$ & The three groups are \\
\hline Married & 3.3400 & .70200 & & & $\begin{array}{l}\text { different: “Single' and } \\
\text { 'Married' are significantly }\end{array}$ \\
\hline $\begin{array}{l}\text { Divorced/ } \\
\text { Separated/ } \\
\text { Widowed }\end{array}$ & 3.5120 & .63414 & & & $\begin{array}{l}\text { different. 'Married' and } \\
\text { 'Divorced/Separated/ } \\
\text { widowed' statistically differs } \\
(\mathrm{p}<.01) .\end{array}$ \\
\hline
\end{tabular}

t-test results of the difference in the stress level of faculty staff based on their work experience

$\begin{array}{lccccc}\text { Experience } & \text { Mean } & \text { Std. Deviation } & \text { t-value } & \text { Sig. } & \text { Remarks } \\ \text { Experienced } & 2.9714 & .16004 & 3.891 & .003^{*} & \begin{array}{c}\text { The two groups were } \\ \text { Lignificant different }(\mathrm{p}<.05) \text {. }\end{array} \text { Less experienced } \\ 3.5238 & .18271 & & & \end{array}$

t-test results of the difference in the stress level of faculty staff the basis of workplace ownership

\begin{tabular}{lcccll}
$\begin{array}{l}\text { Workplace } \\
\text { Ownership }\end{array}$ & Mean & Std. Deviation & t-value & Sig. & Remarks \\
$\begin{array}{l}\text { Public University } \\
\begin{array}{l}\text { Private } \\
\text { University }\end{array}\end{array}$ & 3.0254 & .80002 & 4.570 & $.000 *$ & There is significant difference \\
& & .69021 & & & in the two groups $(\mathrm{p}<.05)$. \\
\hline
\end{tabular}

**. Correlation is significant at the 0.01 level (2-tailed).

*. Correlation is significant at the 0.05 level (2-tailed).

The result in Table 5 indicates that item numbers between 12 to 23 and 25 to 35 respectively had mean scores above the criterion score (2.50) for acceptance level. This implies that the respondents agreed that the listed items were the risk factors associated with occupational stress among university faculty staff. Analysis from Table 5 further revealed that the organizational-related and role-related (cluster mean values of 3.26 respectively) were the highest-ranked risk-factors, associated with occupational stress among university faculty staff in Kwara State. This is closely followed by the physical or environmental-related (cluster mean value of 3.23), personal-related (cluster mean value of 2.77), and lastly the social-related (cluster mean value of 2.73) risk factors.

Table 5: Risk Factors Associated With Occupational-Related Stress.

\begin{tabular}{|c|c|c|c|c|}
\hline S.N. & Items & $\mathbf{X}$ & Std. Deviation & Decision \\
\hline & Personal-related Risk Factors & & & \\
\hline 11 & $\begin{array}{l}\text { Self-perception of been socially discriminated against } \\
\text { in the workplace }\end{array}$ & 2.47 & 1.00 & Rejected \\
\hline 12 & $\begin{array}{l}\text { Pressured to take academic actions that maybe against } \\
\text { individual values upheld. }\end{array}$ & 2.50 & .97 & Accepted \\
\hline 13 & $\begin{array}{l}\text { Pressure to attain set high standard in achieving } \\
\text { personal/ job demand goals }\end{array}$ & 3.57 & .68 & Accepted \\
\hline 14 & Been a perfectionist/workaholics & 2.56 & .85 & Accepted \\
\hline \multirow[t]{2}{*}{15} & Poor health status & 2.77 & .86 & Accepted \\
\hline & Cluster Mean & 2.77 & .87 & Accepted \\
\hline
\end{tabular}




\section{Role-related Risk Factors}

16 Discharging assigned academic and administrative

Accepted

task and responsibilities simultaneously

17 The pressure to complete allocated courses in line

Accepted with the academic calendar and submit student grades.

18 The pressure to attain high scholarship (winning

Accepted research grant, having a requisite number of publications for promotion, and attending workshops and conferences).

19 Teaching workload anomalies (been assigned to teach many courses and large classes, administering and observing student assessment, marking voluminous scripts, and compiling students' results).

20 Mixed engagement of domestic (parental/family) and work duties.

\section{Cluster Mean}

Accepted

\section{Social Risk Factors}

21 Poor social interaction among colleagues/co-workers/ superiors.

Accepted

Accepted

22 Lack of professional support from superiors and

Accepted colleagues

23 Death of spouse/loved ones.

Accepted

24 Attending many social gatherings and functionaries.

25 Strained family relationships or domestic problems/ issues.

\section{Cluster Mean}

Accepted

\section{Physical / Environmental Risk Factors}

26 Commuting anomalies like home-to-work proximity, traffic congestion, vehicle breakdown and conveying public transport.

27 Poor physical environment conditions (hightemperature level, poor office arrangement, noise level, crowded lecture rooms, shortage of electricity and water, poor toilet facilities).

28 Inadequate facilities/resources needed to perform assigned tasks and duties.

Accepted

29 Inadequate physical infrastructure like comfortable office accommodation, lecture rooms, laboratories, workshop, etc

30 Dealing with scary incidents in the discharge of assigned duty e.g. motor accidents, injuries and deaths. 


\section{Organizational-Related}

31 Setting many time-bound deadlines and pressuring

0.72

Accepted staff to meet up

32 Poor motivational support system (e.g irregular

0.30

Accepted payment of bonuses and monetary benefits, unfairness/ partiality in promoting and rewarding best-performing staff, favouritism in selecting staff for development programmes, etc.)

33 Making changes/decisions that affect faculty staff without their due knowledge or participation.

34 Organizational politics, staff-staff conflict and uncongenial work environment.

35 Bureaucracy and red-tapism in the management of university operations

\section{Cluster Mean}

Accepted

2.99

0.98

Accepted

2.59

0.95

Accepted

3.26

.78

Accepted

Key: Mean $<2.50=$ Accepted, while Mean $>2.50=$ Rejected

Findings from Table 6 deduced that the cluster mean values 3.00, and 2.91 of the respondents' response revealed that the social support coping and individually focused coping strategies were moderately adopted for the management of occupational stress among university faculty staff in Kwara State. The cluster-mean value 2.47 was, however, below the 2.50 criterion point, indicates that to a low extent the organizational support coping strategy was adopted in managing occupational stress among faculty staff.

\section{Table 6: Coping Strategies Adopted in Managing Occupational-Related Stress}

\begin{tabular}{|c|c|c|c|c|}
\hline S.N. & Items & $\mathbf{X}$ & Std. Deviation & Decisior \\
\hline & Individual-Focused Coping Strategy & & & \\
\hline 36 & Sectionalizing work and domestic life. & 3.05 & 0.83 & $\mathrm{ME}$ \\
\hline 37 & $\begin{array}{l}\text { Making use of meditation, relaxation (having } \\
\text { adequate rest and sleep, taking holiday and creating } \\
\text { time for leisure activities), and biofeedback (periodic } \\
\text { medical checkup) intervention styles. }\end{array}$ & 3.25 & 0.76 & $\mathrm{HE}$ \\
\hline 38 & $\begin{array}{l}\text { Regular engagement in physical and aerobic exercise } \\
\text { e.g road works, jogging, work-out in fitness centers } \\
\text { and biking. }\end{array}$ & 2.90 & 0.67 & ME \\
\hline 39 & $\begin{array}{l}\text { Adopting labour coping styles like; (a) planning, } \\
\text { prioritizing and working ahead of time to reduce } \\
\text { stressful incidences, (b) effective management of time } \\
\text { in accomplishing tasks, (c) delegating responsibility } \\
\text { to subordinates, and (d) taking a break from work }\end{array}$ & 2.85 & 1.01 & ME \\
\hline 40 & $\begin{array}{l}\text { Deter from being a perfectionist (i.e. feeling that } \\
\text { everything must be done perfectly). }\end{array}$ & 2.71 & 0.98 & ME \\
\hline 41 & $\begin{array}{l}\text { Learning innovative and alternative ways of } \\
\text { discharging duties }\end{array}$ & 2.60 & 0.82 & ME \\
\hline
\end{tabular}


42 Keep an exciting mood by laughing/smile always and

2.99

0.84

ME be surrounded by happy people.

\section{Cluster Mean}

\section{Social Support Coping Strategy}

43 Expressing personal feelings instead of bottling them up.

44 Allowing/building empathetic/and or satisfactory relationships to occur among self, superiors, work colleagues and students

45 Seeking help and support from superiors and colleagues for work-related problems

46 Discussing stressful situations with family members, and trusted friends for advice

47 Attending academic/social functionaries like seminars, talk shows, public lectures, marriages, naming ceremonies, as well as religious activities

48 Using social networking community (Twitter, Facebook, skype, WhatsApp) to ease the stress level

49 Taking guidance/counseling from professional clinical experts

\section{Cluster Mean}

\section{Organizational Support Coping Strategy}

50 Building a strong support and feedback system

51 Reducing tasks and redefining/redesigning work roles, time and schedules

52 Implementing more participative management styles

53 Making the work environment congenial by building cohesive teams

54 Establishing and implementing fair employment and career progression practices

55 Resuscitating the physical/environmental environment of the university.

56 Enacting sustainable welfare programmes to boost the physical and mental health of faculty staff.

57 Organizing and provision of comprehensive educational intervention programmes (counselling, seminars, and workshop) to enhance faculty staff knowledge on stress and its management.

Cluster Mean
2.91

0.84

ME

2.83

0.90

ME

0.74

ME

2.64

0.93

$\mathrm{ME}$

3.10

0.92

ME

3.85

0.51

$\mathrm{HE}$

3.31

0.81

HE

2.58

0.99

ME

3.00

0.83

ME

2.51

1.06

$\mathrm{ME}$

2.59

0.80

ME

2.31

0.98

LE

2.60

1.06

ME

2.55

0.79

ME

2.38

1.03

LE

2.46

0.89

LE

2.39

0.97

LE

Key: 3.25-4.00 = High Extent (HE), 2.50-3.24 = Moderate Extent (ME), and $>2.50=$ Low Extent (LE). This interpretation applies to both individual and grand mean values. 


\section{Outcomes of Findings on Goal Achievement}

The outcomes arising from the research findings are implicated with the attainment of university goals in terms of delivering quality teaching, research, promoting scholarship and community service. Specifically, the high level of occupational-related stress discovered implies that university faculty staff are faced with stress-related challenges which are capable of damaging their cognitive, physiological, emotional/psychological and behavioural personality, health status and wellbeing. These challenges can further lead to a high level of exhaustion and burn out, poor motivation and commitment to work, increased absenteeism from work for no genuine reason, lower level of productivity and effectiveness at work (Foy, 2015; Usoro, 2018) as well as increased complaints from the community at the university, which may defame the university's public image locally and internationally. When situations like these become prevalent, universities are highly implicated as they are less likely to attain their mandates of teaching excellence, quality research output, generation and dissemination of knowledge (FRN, 2013, p.37) and production of quality manpower for the competitive employment market.

The stress level among university faculty staff was found to differ based on social demographic parameters of gender, age, marital status, work experience and workplace ownership. This makes it imperative for university administrators and managers to give adequate attention to the demographic parameters whiledesigning, formulating and implementing personnel or welfare policies for faculty staff. This is to safeguard the overall individual and organisational effectiveness because a happy and less stressed worker is a productive worker.The study also revealed that the risk of occupation related stress among faculty staff emanates from a wide range of organizational, role-related, physical/environmental, personal, and social-related factors. The implication is that it will help to direct the attention of university administrators and the government to the critical role played by the aforementioned risk factors in impeding the effective discharge of statutory job functions (teaching, research and community service) by faculty staff, so as to effectively minimize or mitigate these stressors for the attainment of university goals.

The present study revealed that the social support coping strategies and individual-focused coping strategies were moderately adopted for the management of occupational stress, while the organizational support coping strategies were to a low extent adopted. This finding implies that the faculty staff, social community and university management must adopt/and or provide coping strategies that help faculty staff to adapt to work, become emotionally stable and healthy, and cope with environmental and job demands. This is because coping correctly with stressors facilitates successful adaptation, while a failure in this process put faculty staff and their organizations at risk of poor goal attainment at both the individual and organizational level.

\section{Discussion}

The study revealed that the overall level of occupation-related stress among university faculty staff in Kwara State was high. This finding tallied with those of Kataoka et al. (2014), Masuku and Muchemwa (2015) Zuraida and Nur (2015) but negates that of Azizah et al. (2016), Ismail, Abd Rahman and Zainal Abidin (2014), Ismail and Noor (2016), Noormaliza et al. (2016), Peretomode (2015), and Sabherwal et al. (2015), who found varying stress levels, mainly between low to moderate. These differences might be attributed to the varying work environments in which the faculty staff operate.

The result from the inferential statistical outcome showed that occupation-related stress levels among university faculty staff differs based on social demographic parameters of gender $(p<.05)$, age $(p<.01)$, marital status $(\mathrm{p}<.01)$, work experience $(\mathrm{p}<.05)$ and workplace ownership $(\mathrm{p}<.05)$. The influence of gender on stress level, found in the study, is quite similar to the reports of Azizah et al. (2016), Foy (2015), Kataoka et al. (2014), and Noormaliz et al. (2016). Similarly, Nur Aqilah and Juliana's (2012) research has reported high strain levels among female lecturers in comparison with their male 
counterparts $(\mathrm{p}=0.035)$. This supports the outcome of this study. This finding and those of other studies, as observed by AbdulRaheem, Atunde, Medupin, Awarun and Ayoku (2020), might be attributed to additional gender roles of female faculty staff like combining work duties with marital, domestic and family responsibilities. The results implicate that female academicians who don't have the strength or energy to effectively meet all those demands are likely to encounter high-level stress and other health problems. However, the studies by Ismail and Noor (2016), Masuku and Muchemwa (2015), Nguyen and Nguyen (2017) and Omoniyi (2016) contradict these results.

In terms of age differences ( $\mathrm{p}<.01)$, the findings tally with that of Chaudhry (2013) and Foy (2015), who reported similar research outcomes. This can be attributed to the fact that when individuals continue to grow old, their responsibilities and expectations increase and if they are unable to discover avenues for attaining their expectation, they are susceptible to stress. This, however, negates the results obtained in Masuku and Muchemwa (2015) and Noormaliza et al. (2016), that age is not a key determinant of stress level among university lecturers. Furthermore, the influence of marital status on stress level $(\mathrm{p}<.01)$ discovered in the present study conflict with that of Amoako, Gyamfi, Emmanuel and David (2017) Ismail and Noor (2016) Nguyen and Nguyen (2017) and Noormaliza et al. (2016). The negation of previous studies to this finding is rather surprising considering the observation of Falola, Salau, Omoniyi-Oyafunke and Olokundun (2016) that many faculty staff who are single are enjoying the freedom of having a less number of demands, expectations and responsibilities. Hence they can fully concentrate on their work and even comfortably work extra hours, to fulfill the demands of their work. Unlike the married or separated/divorced/widowed that might be combining marital roles and work expectation and they are likely to experience different aftermath effects of marital problems.

The findings regarding the work experience influence $(\mathrm{p}<.05)$ on stress level negated that of Adebiyi (2013), Amoako et al. (2017), and Ismail and Noor (2016) but aligns with other research carried out by Azizah et al. (2016) and Chaudhry (2013) who reported that faculty staff with lesser work experience had higher stress when compared to more experienced ones. This is because higher job experience provides better opportunities to understand the intricacies of a profession in a better manner. The statistical outcome also showed that occupational-related stress level varies among university faculty staff differs based on workplace ownership $(\mathrm{p}<.05)$. This finding is evident in the high mean scores for the stress level of faculty staff working in private universities than their counterparts in public universities. This might be attributed to the cost-effective approach, mostly utilized by private organizations, in managing their running cost by merging functions of two or three persons for one individual.

The study results also revealed that organizational-related (setting many time-bound deadlines and pressuring staff to meet up poor motivational support system), role-related (pressure to attain high scholarship and teaching workload anomalies), followed by physical/environmental-related (poor physical environmental conditions, inadequate physical infrastructure, and facilities/resources) were highly ranked risk-factors associated with occupational-related stress among university faculty staff in Kwara State. This finding, although not surprising, considers the low extent of organizational support coping strategies adopted for managing occupational-related as found in the study. It, therefore, agrees with other previous studies (Ismail, Abd Rahman \& Zainal Abidin, 2014; Ismail \& Noor, 2016; Masuku \& Muchemwa, 2015; Nguyen \& Nguyen, 2017; Omoniyi, 2016; Sabherwal et al., 2015; Safaria, 2013), which observed that student domain, time-domain, career development domain, work-itself (role ambiguity, conflict and overload), work-family issues, inadequate motivational support and work environment are prevalent risk factors triggering high-level stress among employees in the lecturing profession.

Findings further revealed that social support coping (discussing stressful situations with a social community, attending academic/social functionaries, utilizing social networking community) and individual-focused coping (Making use of meditation, relaxation, and biofeedback intervention styles) 
strategies were moderately adopted for the management of occupational stress. The finding tallies with that of Peretomode (2015), Safaria (2013), who found that the predominant strategies employed by academic staff in managing stress include: work-related social support such as relying on supportive friends, sharing feelings with reliable allies, forgiving others, getting help from a mentor, keeping a sense of humour, physiological activities involving exercises, in-door games, meditation, setting leisure activities time, having adequate sleep, taking vital medications; and interpersonal strategies such as positive thinking, effective use of time, relaxing from routine work among others, etc.

The present study also discovered that the organizational support coping strategies like implementing more participative management styles (2.31), resuscitating the physical environment of the university (2.38), enacting sustainable welfare programmes (2.46) and organizing and provision of comprehensive educational intervention programmes (2.39) were to a low extent adopted for the management of stress. This finding, therefore, emphasizes the need for the university managers to develop programmes that will help to reduce high-stress level among faculty staff. These programmes will help in controlling their turnover, burnout, health issues, absenteeism and strained relationships with the university community. As a result, both individual and organizational goals can be adequately attained.

\section{Conclusion}

Based on the findings of this study, the paper concludes that university faculty staff in Kwara State face stressful work situations, which reflects the high level of occupation-related stress among these academicians. This level of occupation-related stress among university faculty staff can be explained by their social demographic parameters. Additionally, the predominant risk factors contributing to this stress level are mainly organizational, role-related and physical/environmental. Also, social support and individual-focused coping strategies were moderately adopted for the management of occupational stress, while the organizational support coping strategies was utilized to a low extent. These results can, however, impede the attainment of university goals because it will tamper the cognitive, physiological, psychological and behavioural state of faculty staff. This will lead to a destructive work and health anomalies. Therefore, the prevention and management of occupation-related stress among faculty require individual, social support and most especially workplace-level interventions. This is because of how the workplace and its environment can create stress. Given this, faculty staff, as well as university managers, should continually adopt and/or improve the adoption of the coping strategies found in this study for the management of occupational stress. This will help promote a healthy workforce, which will work efficiently and effectively for the attainment of university goals. Also, university managers and administrators should endeavour to promote health awareness knowledge and also establish an effective assistance programme for faculty staff to help identify, refer and recuperate those under highlevel stress. Besides, demographic parameters like gender, age, marital status, experience level and type of organization needs to be considered when assigning duties and responsibilities in order to enhance the productivity of faculty staff.

\section{Conflict of Interest}

The authors declared that there is no conflicting interest in the write-up of this article.

\section{References}

AbdulRaheem, J.W., Atunde, M.O., Medupin, J.A., Awarun, O. \& Ayoku, O. B. (2020). Role conflict and staff productivity in academic libraries: A study of private universities in Kwara State, Nigeria. Texila International Journal of Management, 6 (2), 129 - 138. DOI: 10.21522/TIJMG.2015.06.02.Art014

Amoako, E.P., Gyamfi, O.A., Emmanuel, A.K. \& David, B. (2017). The effect of occupational stress on job performance at Aspet A. company limited. Global Journal of Arts, Humanities and Social Sciences, 5 (8), 1-17. Available online at: www.eajournals.org. 
Atunde, M.O. (2011). Influence of management information system on academic staff effectiveness in Kwara State Colleges of Education (Unpublished M.Ed Thesis). National Open University of Nigeria, Abuja, Nigeria.

Azizah, A., Rozainee K., Nada I., Izreen S. \& Norhafizah Z.I. (2016). The prevalence of occupational stress and its association with socio-demographic factors among lecturers in a private university in Malaysia. International Journal of Public Health and Clinical Sciences, 3 (4), 63 - 71.

Betonio, J.R. (2015). Stress factors and the teaching performance of the college faculty. International Journal of Social Science and Humanity, 5 (7), 651 - 655.

Chaudhry, A.Q. (2013). Analysis of occupational stress of university faculty to improve the quality of their work. Journal of Quality and Technology Management, 9 (1), 12 - 29.

Falola, H. O., Salau, O. P., Omoniyi-Oyafunke, C. \& Olokundun, A. M. (2016). Effect of marital instability on employee performance in selected commercial banks in Nigeria. International Business Management, 10 (21), $5158-5163$.

EOHS (2011, 14 January). Summary of generic prevention and control strategies. Accessed on December 18, 2019 from https:/www.iloencyclopaedia.org/part-v-77965/psychosocial-and-organizational-factors/ prevention/item/69-summary-of-generic-prevention-and-control-strategies

FRN (2013). National policy on education (6th Ed.). Abuja, Nigeria: NERDC Press.

Gawati, F.A. (2017). Job stress and staff performance in national examination council, Minna, Niger State (Unpublished M.Ed thesis). National Open University of Nigeria, Abuja, Nigeria.

Goh, Y. W., Sawang, S. \& Oei, T. P. (2010). The revised transactional model (RTM) of occupational stress and coping: An improved process approach. The Australian and New Zealand Journal of Organisational Psychology, 3, 13-20.

Gunawan, E., Deo, P., Hidayat, T., Pandia, V., Iskandar, S., Yuni, P.S, Sylviana, N., Akbar, I., Farenia, R., Wahyu, K., Purba, A. \& Hatta, S. (2018). Factors correlated with occupational stress among university lecturers. Medicine \& Health, 13(2), 95-102. https://doi.org/10.17576/MH.2018.1302.9

Ismail, N.H. \& Noor, A. (2016). Occupational stress and its associated factors among academician in a research university, Malaysia. Malaysian Journal of Public Health Medicine, 16 (1), 81-91

Ismail, N., Abd Rahman, A. \& ZainalAbidin, E. (2014). Organizational factors associated with occupational stress among lecturers in community colleges, Peninsular Malaysia. Iranian Journal of Public Health, 43 (3), 125-130. Available online at: http://ijph.tums.ac.ir

Kataoka, M., Ozawa, K., Tomotake, M., Tanioka, T. \& King, B. (2014). Occupational stress and its related factors among university teachers in Japan. Health, 6 (5), 299-305. http://dx.doi.org/10.4236/health.2014.65043

Kumar, D.S. \& Rajeswari, V. (2017). A study on stress and job performance among school teachers of Karimnagar City. International Journal of Management, IT \& Engineering, 7 (12), 245 - 257.

Masuku, S. \& Muchemwa, S. (2015). Occupational stress among university lecturers: A case of Zimbabwe. USChina Education Review A, 5 (4), 258-266. DOI: 10.17265/2161-623X/2015.04.003

National Universities Commission (2018). Nigerian university system statistical digest, 2017. Slough, UK and Delhi, India: Sterling Publishers, p. 26 - 29. ISBN: 978-978-965-138-2.

Nkemakolam, E.C. (2016). Work stress and coping strategies among teachers in private primary schools in Owerri Educattion Zone of Imo State (Unpublished M.ED thesis). University of Nigeria, Nsukka, Nigeria.

Nguyen T.M.A \& Nguyen, Q.H. (2017). Relationship between occupational stress among university lecturers and their job satisfaction: A study in Hanoi University of Science And Technology (Vietnam). Proceeding of the 5th International Conference on Emerging Challenges: Strategic Integration (pp.277 - 284). Hanoi, Viet Nam.

Noormaliza, H., Najibah, A.R., Fauzana, M., Azizah, A. \& Nukhdiha, O. (2016). Association between occupational stress and stress biomarkers among lecturers at Universiti Selangor, Shah Alam. Proceedings of UNISEL Bestari Research Projects 2016, Ed(s): SetyawanWidyarto, et.al., Shah Alam: FIIT-UNISEL Publisher, ISBN: 978-983-3757-29-9. $154-157$. 
Omoniyi, M.B.I (2016).Sources of workplace stressors among university lecturers in South West Nigeria: Implication for counselling. Proceedings of the 1st Annual International Interdisciplinary Conference (pp. 589 - 596). Azores, Portugal.

Peretomode, O. (2015). Work and stress among academic administrators of higher education institutions in Delta State. European Scientific Journal, 8 (13), 29 - 36.

Pezaro, S. (2018, March 22). Theories of work-related stress. Retrieved from https://sallypezaro.wordpress. com/2018/03/22/theories-of-work-related-stress/

Sabherwal, N., Ahuja, D., George, M. \& Handa, A. (2015). A study on occupational stress among faculty members in Higher Education Institutions in Pune. SIMS Journal of Management Research, 1, 18 - 23

Safaria, T. (2013). Job stress among academic staff: A cross-cultural qualitative study. International Journal of Public Health Science (IJPHS), 2 (2), 43 - 58.

Usoro, A.A. (2018). Occupational stress and the job effectiveness of federal university lecturers in Cross River and Akwalbom States, Nigeria. European Journal of Business and Management, 10 (14), 79 - 84. 